\title{
MEMÓRIA, HISTÓRIA E TESTEMUNHO NO DIÁRIO DO HOSPÍCIO, DE LIMA BARRETO
}

\author{
João Gonçalves Ferreira Christófaro Silva
}

Mestrando em Literatura Brasileira do Programa de Pós-Graduação em Estudos Literários /

UFMG

\section{RESUMO}

Pretendemos pensar o Diário do hospício a partir de teorizações sobre o testemunho, embora respeitando as particularidades do diário. A obra parece aceitar interpretações múltiplas, apresentando-se tanto como testemunho de um sistema específico de exclusão quanto como produção da uma autoimagem de Lima Barreto enquanto escritor.

\section{PALAVRAS-CHAVE}

Diário de escritor, testemunho, imagem do escritor

"Estou no Hospício ou, melhor, em várias dependências dele, desde o dia 25 do mês passado. Estive no pavilhão de observações, que é a pior etapa de quem, como eu, entra para aqui pelas mãos da polícia."1 Com essas palavras, em entrada de 4 de janeiro de 1920, Afonso Henriques de Lima Barreto inicia seu Diário do hospício, em que trata de sua segunda internação no Hospício Nacional de Alienados (HNA), que durou de 25 de dezembro de 1919 a 2 de fevereiro de 1920. Tendo passado a noite da véspera de Natal "em claro, errando pelos subúrbios, em pleno delírio", 2 causado pelo álcool, é internado justamente com o diagnóstico de alcoolismo.

O Diário do hospício não é um texto longo: é formado por diversas entradas bem curtas e pontuais e nove entradas um pouco mais extensas, em que são tratados diversos assuntos referentes ao hospício e à sua internação, tais como a rotina do hospital, sua organização, os

\footnotetext{
${ }^{1}$ BARRETO. Um longo sonho do futuro: diários, cartas, entrevistas e confissões dispersas, p. 153.

${ }^{2}$ BARRETO. Um longo sonho do futuro: diários, cartas, entrevistas e confissões dispersas, p. 154.
} 
médicos, os enfermeiros, os outros doentes, o sentido da loucura e o sentido da sua loucura, a ciência psiquiátrica, etc., além de pensamentos sobre a escrita e a literatura, anotações sobre outros livros e autores (Lima Barreto diz que um dos motivos de seu pedido para ser transferido da Seção Pinel, reservada aos indigentes, para a Seção Calmeil, destinada aos pensionistas, era a possibilidade de frequentar a biblioteca que ali havia), reflexões sobre sua carreira literária, sobre sua família, enfim, sobre os mais diversos tópicos, como é comum na escrita diarística. Há de se frisar, ainda, a intenção declarada do autor de usar as notas para a escritura de um romance: Cemitério dos vivos, que permaneceria inacabado, sendo mesmo assim publicado, postumamente, em conjunto com o diário em questão.

Como se vê, apesar de sua pequena extensão, são numerosas as possibilidades de abordagem desse diário. Tentaremos nos focar, aqui, nas possíveis interseções entre memória pessoal e história, tentando investigar o Diário do hospício ao mesmo tempo enquanto documento para a história - principalmente no que diz respeito à história da psiquiatria no Brasil - e escrita de si, que participa também da construção de uma imagem de si que, no caso de escritores públicos, chega à posteridade como uma espécie de memória do que estes teriam sido. Buscaremos, também, pensar a questão do diário enquanto documento histórico e memória pessoal a partir de suas relações de oposição ou contiguidade com teorias acerca do testemunho, tanto no âmbito latino-americano quanto no germânico, sempre respeitando suas condições de escrita e suas particularidades estruturais que muito diferem do que se costuma chamar de "testemunho".

\section{DIÁRIO, MEMÓRIA, HISTÓRIA}

Como indica Mathias, ${ }^{3}$ é possível colocar os diários ao lado dos escritos que, em geral, atribuem centralidade à questão da memória, como as autobiografias ou as próprias memórias. É possível relacioná-los com esses outros gêneros também pela questão do pacto autobiográfico -“a coincidência entre autor, narrador e personagem". Mas podemos também diferenciar o tratamento atribuído à memória e ao passado nesses gêneros. Se nas autobiografias e memórias,

\footnotetext{
${ }^{3}$ MATHIAS. Autobiografias e diários, p. 41.

${ }^{4}$ MATHIAS. Autobiografias e diários, p. 41.
} 
temos, segundo Mathias, ${ }^{5}$ uma composição de conjunto, fechada e coerente, que se desenvolve em uma linha visível e demanda uma leitura linear, que em geral se fecha em um balanço final ou conclusão que confirma a unidade pretendida pela narrativa, nos diários encontramos a escrita em uma página aberta à qual se recorre de acordo com o momento, não havendo normas, regras ou horários, em que a escrita aparece em uma linha descontínua, formada por acúmulo, que permite e até incentiva uma leitura irregular, saltitante, em acordo com a pluralidade, em acordo com a pluralidade própria ao diário. Ainda segundo Mathias, pode-se diferenciá-los especificamente quanto à noção de tempo, que "na autobiografia resume uma totalidade, reconstituição de um passado morto, quando no diário é a sismografia do próprio tempo presente a emergir e sumirse." 6

O diário, pelo seu próprio tempo de escrita, está sempre sujeito ao dia e às vicissitudes dos pensamentos e atos diários. Isso faz com o que a memória e o passado nele inscritos estejam menos sujeitos ao controle do escritor. É claro que não é o caso de atribuir aleatoriedade ou inocência às entradas dos diários de escritor. Em primeiro lugar, há indícios claros de que os escritores desconfiavam e até contavam com a publicação de seus escritos pessoais - veja-se o seguinte trecho do Diário íntimo de Lima Barreto, também publicado postumamente, em que o escritor refere-se ao destino de suas notas: "Aqui bem alto declaro que, se a morte me surpreender, não permitindo que as inutilize, peço a quem se servir delas que se sirva com o máximo cuidado e discrição, porque mesmo no túmulo eu poderei ter vergonha." ${ }^{, 7}$ Além disso, há, de qualquer maneira, seleção, a cada entrada, do que vai e do que não vai ser registrado. O que acontece é que não há um parâmetro soberano ou uma finalidade capaz de reger e conectar todas as escolhas. Podemos dizer, seguindo Ávila ${ }^{8}$ e Lis, ${ }^{9}$ que há, nos diários, uma falta de completude, totalidade e coerência que acaba por afastar conclusões definitivas e precisas de todo tipo, evitando conexões mecânicas e redutoras: formado de entradas de todos os tipos e assuntos, frequentes ou não, periódicas ou não, nem sempre datadas, com variantes formais e

\footnotetext{
${ }^{5}$ MATHIAS. Autobiografias e diários, p. 45-46.

${ }^{6}$ MATHIAS. Autobiografias e diários, p. 46.

${ }^{7}$ BARRETO. Um longo sonho do futuro: diários, cartas, entrevistas e confissões dispersas, p. 44, grifos nossos.

${ }^{8}$ ÁVILA. Invenção e inventário no diário de escritor.

${ }^{9}$ LIS. Le journal d'écrivain en France dans la 1 ère moitié du XXe siècle: à la recherche d'un code générique.
} 
conteudísticas diversas em seu texto, em que muitas vezes encontramos trechos que se contradizem, na sua leitura muitas vezes nos deparamos com escritos que nos deixam ver apenas o reflexo do que procurávamos, a refração do que talvez esperássemos que fosse dito com clareza, o vulto de algo que não conseguimos dizer exatamente o que seria.

Trazendo essas hipóteses para a discussão sobre a memória e a história, podemos dizer que o diário impede, quase que estruturalmente, que nos aproximemos do passado, seja ele estritamente pessoal ou não, de uma forma inocente e com uma vontade totalizante. O diário é paratático, e os fragmentos não se encontram em relação explícita uns com os outros. A ligação entre eles só é possível a partir da construção de roteiros de leitura possíveis, que não podem, no entanto, se afirmar como absolutamente corretos ou verdadeiros em detrimento de outros. É Carmen Lúcia Negreiros de Figueiredo quem, em estudo sobre outro conjunto de arquivos fragmentários de Lima Barreto, que ela denominou Retalhos, sugere a necessidade dessas hipóteses de roteiros de leitura, que, acredito, também são necessárias na leitura de diários. A autora alerta também para o obstáculo que a fragmentação dos Retalhos impõe a respostas culturais prontas. Acreditamos que esse alerta também seja válido para a reflexão sobre memória e história nos textos de que estamos tratando aqui:

A constituição dos Retalhos define um tipo de registro que reflete uma suspeita em relação aos projetos de ordenação linear da história e da cultura, associada, ainda, à apresentação da fragilidade e fragmentação da subjetividade. Esse tecido composto de "retalhos" de relatos sócio-históricos e culturais (com anotações de ordem pessoal, recortes de livros e jornais, recortes de críticas literárias, observações críticas sobre as esquisitices observadas no cotidiano, capazes de sugerir a produção de conto, etc.), ao mesmo tempo em que forma um painel múltiplo, heterogêneo, contraditório, é extremamente instigante, não por guardar confidências, mas porque o recorte, entre fragmentos, deixa em silêncio possíveis soluções e respostas estereotipadas a dilemas culturais que ainda hoje incomodam o leitor. ${ }^{10}$

Os recortes e lacunas com os quais nos deparamos nos diários de Lima Barreto podem servir para silenciar algumas soluções estereotipadas dadas como resposta à sua própria figura que, a nosso ver, encontra-se hoje excessivamente imobilizada e, portanto, ligeiramente esterilizada no cenário cultural brasileiro. Ainda, acreditamos que toda esta reflexão acerca da impossibilidade de controle e totalização desse tipo de conjunto vai ao encontro de diversas teorias sobre a história que tratam da impossibilidade de apreender total e objetivamente o

\footnotetext{
${ }^{10}$ FIGUEIREDO. O arquivo e o olhar: da vida literária à rede de imagens culturais, p. 86.
} 
passado: tais recortes e lacunas podem nos colocar diante de uma perspectiva pertinente em relação à boa parte da historiografia de nosso tempo, que busca levar em conta também o esquecimento, a falha e os relatos e memórias pessoais. Seligmann-Silva, logo no início de seu texto intitulado "Reflexões sobre a memória, a história e o esquecimento", escreve:

A historiografia tal como o século XX a conheceu é uma invenção do século anterior. Pode-se dizer - com Walter Benjamin - que essa historiografia representaria mais um dos sonhos que penetraram o umbral da nossa Era. Ao que tudo indica, estamos despertando desse sonho ou pesadelo - recorrente - do historicismo, que acreditou na possibilidade de se conhecer o passado "tal como ele de fato ocorreu". Não apenas Benjamin foi um dos maiores responsáveis pelo despertar desse sonho e pela sua interpretação, já que Nietzsche no seu texto "Dos usos e desvantagens da história para a vida" (...) afirmara que "es ist (...) ganz und gar unmöglich, ohne Vergessen überhaupt zu leben" [é totalmente impossível de se viver sem o esquecimento] $(. . .)^{11}$

Em outro trecho, agora tirado das teses "Sobre o conceito da história", de Walter Benjamin, podemos ver o quanto há, também, de ético e político nessa negação da apreensão total da história:

Fustel de Coulagers recomenda ao historiador interessado em ressuscitar uma época que esqueça tudo o que sabe sobre fases posteriores da história. Impossível caracterizar melhor o método com o qual rompeu o materialismo histórico. Esse método é o da empatia. Sua origem é a inércia do coração, a acedia, que desespera de apropriar-se da verdadeira imagem histórica, em seu relampejar fugaz. Para os teóricos medievais a acedia era o primeiro fundamento da tristeza. (...) A natureza dessa tristeza se tornará mais clara se nos perguntarmos com quem o investigador historicista estabelece uma relação de empatia. A resposta é inequívoca: com o vencedor. Ora os que num momento dado dominam são os herdeiros de todos os que venceram antes. A empatia com o vencedor beneficia sempre, portanto, esses dominadores. ${ }^{12}$

Por fim, cabe ressaltar a "nova ética e estética da historiografia" de que fala SeligmannSilva, ${ }^{13}$ que teria surgido como resposta às diversas catástrofes do século 20 , especialmente ao massacre dos judeus na Segunda Guerra Mundial. Ainda segundo o autor, essas novas formas de representação do passado poderiam "ser reunidas, grosso modo, sob o signo da nova desconfiança diante das categorias universais" e da perda de sentido de conceitos iluministas

\footnotetext{
${ }^{11}$ SELIGMANN-SILVA. Reflexões sobre a memória, a história e o esquecimento, p. 60, tradução do autor.

${ }^{12}$ BENJAMIN. Obras escolhidas volume I: Magia e técnica, arte e política, p. 225.

${ }^{13}$ SELIGMANN-SILVA. Reflexões sobre a memória, a história e o esquecimento, p. 65.
} 
como progresso e ascensão linear da história. Diante de tais desconfianças, o registro da memória passa a ganhar valor: "Em contrapartida, observou-se mais e mais a ascensão do registro da memória - que é fragmentário, calcado na experiência individual e da comunidade, no apego a locais simbólicos e não tem como meta a tradução integral do passado."14

Não tentaremos, portanto, entrar em contato com a época em que o Diário do hospício de Lima Barreto foi escrito através da empatia, época esta dominada justamente pelo positivismo e cientificismo dos quais o sonho de uma história total e objetiva é irmão. Buscaremos observar as conexões possíveis entre esse escrito pessoal e a história, assumindo a escrita fragmentada, subjetiva e interessada de Lima Barreto como perspectiva rica para trazer à tona certos acontecimentos, práticas e questões que provavelmente seriam esquecidas em uma historiografia supostamente total, objetiva e isenta.

\section{DIÁRIO DO HOSPÍCIO E TESTEMUNHO}

Faremos, agora, uma rápida reflexão acerca de algumas teorias que tratam do testemunho, na tentativa de delimitar mais propriamente algumas das categorias às quais poderemos recorrer para pensar as articulações possíveis entre história e memória no Diário do hospício e, em seguida, desenvolver a discussão a partir de tais categorias. Os teóricos consultados tendem a estabelecer duas linhas principais de pensamento sobre o assunto: uma germânica e uma latinoamericana, sendo que nesta última é possível perceber a distinção, em alguns teóricos, entre duas acepções do termo. Ao testemunho entendido como o fazem os pensadores que seguem a tendência germânica, chamaremos Zeugnis, e ao testemunho como é entendido no âmbito dos estudos latino-americanos, chamaremos testimonio, seguindo as denominações das línguas em que se originam tais reflexões.

Seligmann-Silva, em um texto bastante claro e objetivo, “'Zeugnis' e 'Testimonio': um caso de intraduzibilidade entre conceitos", procura definir e distinguir bem resumida e esquematicamente os dois conceitos a partir das seguintes categorias: o evento, a pessoa que testemunha, o testemunho, a cena do testemunho e a literatura de testemunho.

\footnotetext{
${ }^{14}$ SELIGMANN-SILVA. Reflexões sobre a memória, a história e o esquecimento, p. 65.
} 
No âmbito germânico, o evento central seria a Shoah, tomado em sua "radicalidade e consequente singularidade", ${ }^{15}$ que impossibilita a sua comparação com outras catástrofes e a coloca para além de toda compreensão. $\mathrm{O}$ evento catastrófico seria um evento singular porque "mais do que qualquer fato histórico, do ponto de vista das vítimas e das pessoas nele envolvidas, ele não se deixa reduzir em termo de discurso". ${ }^{16}$ A pessoa que testemunha é "pensada na chave da noção freudiana de trauma ou dentro de abordagens lacanianas - quando se enfatiza a noção de real como algo que não pode ser simbolizado (...)", ou em desdobramentos dessas noções oriundas da psicanálise. Há a figura da testemunha enquanto testis (no caso de "testemunhas secundárias"), figura jurídica de um terceiro que, no tribunal, dá a sua versão dos "fatos", e enquanto superstes (no caso dos sobreviventes, consideradas, geralmente, as testemunhas primárias), alguém que sobreviveu a um evento e pode, portanto, dar testemunho acerca dele. No entanto, enfatiza-se que a testemunha enquanto superstes não consegue dar conta do vivido tanto pelo trauma que sofreu quanto pela dimensão da catástrofe. O testemunho se caracteriza pela literalização, "incapacidade de traduzir o vivido em imagens e metáforas"17 e pela fragmentação, enquanto incapacidade de ordenar linearmente as imagens que marcam a memória dos traumatizados. Pensado na chave do trauma e da intraduzibilidade, o testemunho também parece ter uma função terapêutica. A cena do testemunho é tanto a cena do tribunal, cumprindo um papel de justiça histórica e servindo como documento para a história, quanto o "momento de perlaboração do passado traumático". Soma-se, ainda, o papel aglutinador dos judeus, que constroem sua identidade a partir da identificação dessa história catastrófica. Por fim, a literatura de testemunho não procura ser definida de modo estrito, o que não impede que haja um cânone estabelecido dessa literatura; a força recai sobre o próprio conceito de testemunho e a presença desse elemento nas obras dos sobreviventes da Shoah ou de autores que tratam das diversas catástrofes do século 20 .

No âmbito latino-americano, ressalta-se convergência entre política e literatura. ${ }^{18} \mathrm{O}$ evento não é caracterizado pela singularidade ou unicidade. Ao contrário, "enfatiza-se a

\footnotetext{
${ }^{15}$ SELIGMANN-SILVA. "Zeugnis" e "Testimonio": um caso de intraduzibilidade entre conceitos, p. 122.

${ }^{16}$ SELIGMANN-SILVA. "Zeugnis" e "Testimonio": um caso de intraduzibilidade entre conceitos, p. 123.

${ }^{17}$ SELIGMANN-SILVA. "Zeugnis" e "Testimonio": um caso de intraduzibilidade entre conceitos, p. 123.

${ }^{18}$ SELIGMANN-SILVA. "Zeugnis" e "Testimonio": um caso de intraduzibilidade entre conceitos, p. 125.
} 
continuidade da opressão e a sua onipresença no "continente latino-americano",, 19 da qual o testemunho deve dar registro histórico, fixando-se como uma contra-história. Quanto à pessoa que testemunha, enfatiza-se a caracterização da testemunha enquanto testis, terceiro que comprova e certifica a verdade dos fatos, destacando-se não a indizibilidade e subjetividade da vivência, mas seu caráter coletivo. Assim, a testemunha aparece como o representante de uma coletividade. Há, dessa maneira, a tendência para uma simbiose entre história e memória. Destaca-se, ainda, como no caso dos autores de Zeugnis, a necessidade de se testemunhar, mas aqui entendida "quase que exclusivamente em um sentido de necessidade de se fazer justiça, de se dar conta da exemplaridade do 'herói' e de se conquistar uma voz para o 'subalterno'., ${ }^{20}$ No que diz respeito ao testemunho, o realismo das obras é enfatizado, e sublinha-se o seu caráter antiestetizante e a estratégia de apresentação do documento histórico, em detrimento da ênfase na subjetividade. Seu caráter não fictício coincide com o testemunho da Shoah, mas soma-se a isso seu caráter exemplar e a marca profunda da oralidade. A oralidade aparece como marca importante, na medida em que o testimonio, como entendido hegemonicamente, muitas vezes exige um mediador/compilador, pelo fato de as testemunhas serem, em sua maioria, analfabetas. Nesse sentido, tende-se a considerar o mediador como uma figura transparente, mero porta-voz. A cena do tribunal prevalece no que diz respeito à cena desse testemunho. A função de aglutinação social em termos de uma mesma luta também é fundamental. A conjugação de cena do tribunal e caráter predominantemente político torna necessária a identificação dos leitores com as testemunhas, para que a obra não seja tachada de mera publicidade ideológica. Por fim, a literatura de testemunha estaria vinculada "aos gêneros da crônica, confissão hagiografia, autobiografia, reportagem, diário e ensaio". ${ }^{21}$

Em artigo intitulado "A literatura de testemunho e a violência de Estado", Valeria de Marco procura distinguir, ainda, dentro do âmbito do testemunho como pensado na América Latina, duas acepções de testemunho, que representariam "duas interpretações diferentes para o resgate da história". ${ }^{22}$ Um primeiro sentido, quase hegemônico, teria emergido na década de 1980, tendo como paradigma o testemunho de Rigoberta Menchú. Segundo a autora:

\footnotetext{
${ }^{19}$ SELIGMANN-SILVA. "Zeugnis" e "Testimonio": um caso de intraduzibilidade entre conceitos, p. 126.

${ }^{20}$ SELIGMANN-SILVA. "Zeugnis" e "Testimonio": um caso de intraduzibilidade entre conceitos, p. 126.

${ }^{21}$ SELIGMANN-SILVA. "Zeugnis" e "Testimonio": um caso de intraduzibilidade entre conceitos, p. 127.

${ }^{22}$ MARCO. A literatura de testemunho e a violência de Estado, p. 45.
} 
O perfil do texto literário seria a constituição do objeto livro como resultado do encontro entre um narrador "de ofício" e um narrador que não integra os espaços de produção de conhecimento considerados legítimos, mas cuja experiência, ao ser contada e registrada, constitui um novo saber que modifica o conhecimento sobre a sociedade até então produzido. Desenha-se o testemunho com traços fortes de compromisso político: o letrado teria a função de recolher a voz do subalterno, do marginalizado, para viabilizar uma crítica e um contraponto à "história oficial", isto é, à versão hegemônica da História. O letrado editor/organizador do texto - é solidário e deve reproduzir fielmente o discurso do outro; este se legitima por ser representativo de uma classe, uma comunidade ou um segmento social amplo e oprimido. ${ }^{23}$

Ainda nessa acepção de testemunho, teríamos a recorrência de duas formulações acerca de sua relevância: esses textos imporiam a necessidade de se repensar cânones literários na medida em que aparecem como questionamentos da periferia em relação ao centro e, além disso, teriam um caráter democrático, visto que viabilizam "a entrada na cultura letrada de vozes de outras identidades, das vozes até então silenciadas, do texto produzido a partir de espaços externos ao poder constituído, da interpretação 'não-oficial' da História". 24

Valeria de Marco critica essa delimitação teórica do testemunho por dois motivos: pela "insistência em normatizar a literatura de testemunho que, como toda forma, e talvez esta de maneira mais radical, não se submete docilmente a moldes", ${ }^{25}$ e pela interpretação ideológica do século 20 que subjaz a ela. Segundo a autora, a insistência militante no caráter democratizante dessa literatura projeta sobre o século 20 a imagem de um século marcado por um "processo histórico de inclusão social", ${ }^{26}$ deixando de lado as tensões e violências que marcaram o século 20 como a "era da catástrofe", como o chamou Hobsbawm. Tal visão otimista do século (que, aliás, contém muito da noção de progresso histórico criticada por parte da historiografia do século 20) tende a não dialogar com o pensamento sobre a literatura de Zeugnis, que interpreta o século 20 como século de barbárie e violência. No âmbito dessa interpretação, a autora destaca as contribuições de Bauman, que propõe a necessidade de examinar a Shoah como "uma possibilidade que a modernidade contém", 27 sendo um dos resultados possíveis do processo civilizador, e as interpretações de Agamben sobre o Estado moderno, que se definiria por e

\footnotetext{
${ }^{23}$ MARCO. A literatura de testemunho e a violência de Estado, p. 46.

${ }^{24}$ MARCO. A literatura de testemunho e a violência de Estado, p. 48.

${ }^{25}$ MARCO. A literatura de testemunho e a violência de Estado, p. 49.

${ }^{26}$ MARCO. A literatura de testemunho e a violência de Estado, p. 49.

${ }^{27}$ MARCO. A literatura de testemunho e a violência de Estado, p. 55.
} 
dependeria de zonas de exclusão a partir das quais se delimitariam o lugar dos incluídos e o espaço político. Embora mudem os habitantes de cada zona, ambas devem sempre existir. Segundo a autora, podemos tirar daí uma interpretação do século 20 "como um processo histórico e social de sistemática exclusão". 28

A segunda acepção de testemunho no âmbito dos estudos latino-americanos poderia dialogar melhor com essa interpretação do século passado, possibilitando uma melhor compreensão da literatura produzida por prisioneiros políticos das ditaduras da América Latina, que poderia ser analisada "em um contexto mais amplo, que ultrapassa limites geográficos do continente e aproxima-a à geografia mundial da barbárie, impondo a necessidade de examinar as relações entre violência, representação e formas literárias". ${ }^{29}$ Em primeiro lugar, essa segunda acepção definiria a literatura de testemunha de forma bem mais flexível, tendo sido definida pelo avesso por Manuel Galich - pelas suas diferenças em relação a gêneros como reportagem, narrativa ficcional, pesquisa e biografia. Em segundo lugar, embora mantendo a vinculação entre testemunho e compromisso político com as lutas sociais, e até mesmo entre testemunho e contrahistória, não há necessidade da figura de um “outro", e, se ela estiver presente, não é necessário que esteja restrita a iletrados, subalternos ou excluídos dos espaços legítimos de produção de conhecimento e cultura. Quando se fala de oprimido, este se identifica mais à figura do opositor político, que é, na maioria das vezes, um intelectual letrado.

Poderíamos tentar, agora, pensar o Diário do hospício a partir de algumas das categorias propostas por Seligmann-Silva, com o apoio das reflexões de Valeria de Marco. Trataremos majoritariamente do evento, da pessoa que testemunha e do testemunho, por acreditarmos que essas são as questões mais frutíferas e pertinentes para a reflexão a qual nos propusemos. Nosso objetivo não é dizer se o texto em questão poderia ser mais bem analisado a partir de um ou outro ponto de vista acerca do testemunho, ou em qual gênero de testemunho se enquadraria, mas pensá-lo a partir de possíveis pontos de proximidade ou afastamento com as teorias que tentamos brevemente apresentar.

\section{O EVENTO}

\footnotetext{
${ }^{28}$ MARCO. A literatura de testemunho e a violência de Estado, p. 56-57.

${ }^{29}$ MARCO. A literatura de testemunho e a violência de Estado, p. 51.
} 
A questão que surge de imediato é: é possível falar da segunda internação de Lima Barreto no Hospital Nacional de Alienados em termos de evento, no sentido em que essa palavra assume nas grandes linhas de pensamento acerca do testemunho? Como vimos, no âmbito germânico as catástrofes, especialmente a Shoah, aparecem como eventos paradigmáticos. Tais eventos, nos quais poderíamos incluir as guerras, os genocídios e, como Valeria de Marco parece sugerir, as ditaduras latino-americanas, são muito mais centrais e delimitados do que as práticas de internação forçada e tratamento psiquiátrico do início do século 20 , que aconteceram de forma diluída em diversas épocas e regimes e que ainda hoje muitas vezes são entendidas como apenas um estágio da evolução da ciência psiquiátrica. Poderíamos entendê-la como mais um ponto na contínua e onipresente opressão no continente latino-americano, mas isso esbarraria no mesmo tipo de problema: essa opressão não se limita ao nosso continente. Traz, ainda, o traço distintivo de se exercer com o aval da ciência tomada como verdade, e não a partir diretamente de um poder opressor. Como mostra Raul Max Lucas da Costa, o tratamento psiquiátrico do alcoolismo era justificado pela teoria da degenerescência, que ligava raça, pobreza, álcool, loucura e caos social:

\begin{abstract}
A teoria da degenerescência se apresentava como um argumento central para a concepção do álcool como uma substância nociva. Estabelecida por Morel, essa teoria defendia a idéia de que fatores internos como a constituição racial; e externos como o ambiente e substâncias tóxicas, seriam causas determinantes na degeneração do organismo humano. Sampaio recorreu ao quadro da geração dos alcoólatras de Morel para demonstrar os efeitos degenerativos do álcool na descendência humana:

$1^{\text {a }}$ Geração: - immoralidade, depravação, embrutecimento moral.

$2^{\mathrm{a}}$ “": - embriaguez hereditaria, acessos maníacos, paralysia geral.

$3^{\mathrm{a}}$ “: - tendências hypocondriacas, delírio persecutório, tendências

homicidas

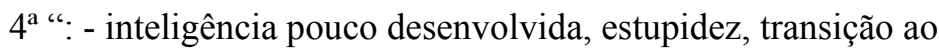

idiotismo, extincção provável da raça.

Dessa forma, na lógica higienista, o álcool era o "laxismo causal", o intermediário direto da decadência humana e das doenças atribuídas aos pobres. O alcoolismo manteria uma relação proporcional com a loucura e com o crime; quanto maior o consumo alcoólico, maior seria a incidência desses fatores. ${ }^{30}$
\end{abstract}

Se não podemos associar satisfatoriamente o evento da internação e do tratamento psiquiátricos aos eventos paradigmáticos do Zeugnis e do testimonio, podemos, no entanto, relacioná-lo com as interpretações da modernidade tecidas por Bauman e Agamben para pensar a Shoah. Com Bauman, podemos pensar o evento da internação psiquiátrica forçada como

\footnotetext{
${ }^{30}$ COSTA. Alcoolismo, discurso científico e escrita de si no Diário do hospício de Lima Barreto, p. 202.
} 
vivenciada por Lima Barreto como uma possibilidade da modernidade e do processo civilizador do qual faz parte a ânsia da racionalidade por se impor acima de tudo. Com Agamben, podemos pensar na instituição psiquiátrica como pertencente a essa zona de exclusão sempre presente na modernidade, onde habitam os portadores de uma vida não qualificada e a partir da qual se define o lugar dos incluídos, dos cidadãos. Pensando assim, podemos estabelecer o evento em questão como mais um dentre os eventos que caracterizam a modernidade como um processo de possibilidades violentas e de sistemática exclusão. Essa exclusão pode ser entendida tanto no âmbito brasileiro - poderíamos falar, com Daniela Birman, de um "projeto político e psiquiátrico de exclusão dos 'doentes mentais' do espaço público da Primeira República"31 - quanto num âmbito geral de exclusão da diferença e negação da própria cidadania a esta.

O evento de sua internação é abordado por Lima Barreto de diferentes maneiras: a descrição do ocorrido e de fatos rotineiros se mescla a lembranças, digressões, tentativas de interpretação de sua própria situação, entre outras coisas. Há uma forte presença da dúvida e da incerteza perante a sua situação e os motivos que levaram a ela. O evento vai sendo observado de diferentes perspectivas, à medida que o escritor vai sendo transferido de pavilhão ou seção. Ele começa, para Lima Barreto, com a entrada pela polícia e a passagem pelo pavilhão de observações que, como no trecho citado logo no início deste texto, é indicado como o pior para quem chega pelas mãos da polícia. Em seguida, é transferido para a Seção Pinel, a seção dos indigentes, em que há a necessidade de trabalho compulsório e um desamparo muito maior do que na sua instalação seguinte, a Seção Calmeil, destinada aos pensionistas.

Lima Barreto nos deixa entrever, em primeiro lugar, a ligação institucional existente entre medicina e polícia, que Costa compreende como "uma prática de controle social junto à população suburbana da cidade, sobretudo aqueles considerados loucos e alcoólatras", 32 que teria a "função normativa e disciplinar junto àqueles que viviam como excedentes ociosos no espaço urbano". 33

Tiram-nos a roupa que trazemos e dão-nos uma outra, só capaz de cobrir a nudez, e nem chinelos ou tamancos nos dão. Da outra vez que lá estive me deram essa peça do vestuário que me é hoje indispensável. Desta vez, não. O enfermeiro antigo era humano e bom; o atual é um português (o outro o era)

\footnotetext{
${ }^{31}$ BIRMAN. Escrita e experiência do cárcere em Lima Barreto e Graciliano Ramos, p. 80.

${ }^{32}$ COSTA. Alcoolismo, discurso científico e escrita de si no Diário do hospício de Lima Barreto, p. 193.

${ }^{33}$ COSTA. Alcoolismo, discurso científico e escrita de si no Diário do hospício de Lima Barreto, p. 193.
} 
arrogante, com uma fisionomia bragantina e presumida. Deram-me uma caneca de mate e, logo em seguida, ainda dia claro, atiraram-me sobre um colchão de capim com uma manta pobre, muito conhecida de toda a nossa pobreza e miséria.

Não me incomodo muito com o hospício, mas o que me aborrece é essa intromissão da polícia na minha vida. ${ }^{34}$

Além disso, podemos observar, na própria trajetória do escritor dentro do hospício, como este era minuciosamente organizado. Podemos pensar, aí, na sistematização e racionalização da exclusão.

Embora Lima Barreto afirme, na passagem acima, não se incomodar com o hospício, e embora também se lamente, em certo momento, por não ter seguido a decisão de não beber, que teria tomado na juventude após ler um livro de Maudsley, ${ }^{35}$ em diversos outros momentos de seu texto podemos observar uma profunda insatisfação com o hospício e o questionamento sistemático dos seus princípios e dos pressupostos científicos que legitimavam a exclusão que ali se operava - como havíamos afirmado, a contradição e a incoerência são itens constitutivos dos diários. A citação é longa, mas significativa:

Que dizer da loucura? Mergulhado no meio de quase duas dezenas de loucos, não se tem absolutamente uma impressão geral dela. Há, como em todas as manifestações da natureza, indivíduos, casos individuais, mas não há ou não se percebe entre eles uma relação de parentesco muito forte. Não há espécies, não há raças de loucos; há loucos só.

(...)

Há uma nomenclatura, uma terminologia, segundo este, segundo aquele; há descrições pacientes de tais casos, revelando pacientes observações, mas uma explicação da loucura não há.

Procuram os antecedentes do indivíduo, mas nós temos milhões deles e, se nos fosse possível conhecê-los todos, ou melhor, ter memória dos seus vícios e hábitos, é bem certo que, nessa população que cada um de nós resume, havia de haver loucos, viciosos, degenerados de toda a sorte.

De resto, quase nunca os filhos dos loucos são gerados quando eles são loucos; os filhos de alcoólicos, da mesma forma, não o são quando seus pais chegam ao estado agudo do vício e, pelo tempo da geração, bebem como todo o mundo.

Todas essas explicações da origem da loucura me parecem absolutamente pueris. Todo o problema de origem é sempre insolúvel; mas não queria já que determinassem a origem, ou explicação; mas que tratassem e curassem as mais simples formas. Até hoje, tudo tem sido em vão, tudo tem sido experimentado; e os doutores mundanos ainda gritam nas salas diante das moças embasbacadas, mostrando os colos e os brilhantes, que a ciência tudo pode.

\footnotetext{
${ }^{34}$ BARRETO. Um longo sonho de futuro: diários, cartas, entrevistas e confissões dispersas, p. 153.

${ }^{35}$ BARRETO. Um longo sonho de futuro: diários, cartas, entrevistas e confissões dispersas, p. 161.
} 
Se a estátua de Isis lá estivesse, havia de cerrar mais o véu impenetrável que cobre o seu rosto. Essa questão do álcool, que me atinge, pois bebi muito e, como toda a gente, tenho que atribuir as minhas crises de loucura a ele, embora sabendo bem que ele não é o fator principal, acode-me refletir por que razão os médicos não encontram no amor, desde o mais baixo, mais carnal, até a sua forma mais elevada, desdobrando-se num verdadeiro misticismo, numa divinização do objeto amado; por que - pergunto eu - não é fator de loucura também?

Por que a riqueza, base da nossa atividade, coisa que, desde menino, nos dizem ser o objeto da vida, da nossa atividade na terra, não é também a causa da loucura?

Por que as posições, os títulos, coisas também que o ensino quase tem por meritório obter, não é causa de loucura? ${ }^{36}$

\section{A Pessoa QUe TESTEMUNHA}

Podemos considerar Lima Barreto tanto testis - o terceiro da cena jurídica que relata sua versão dos fatos, comprovando e os certificando - quanto superstis - o sobrevivente, o que sobreviveu a um evento e por isso é capaz de dar testemunho sobre ele.

Birman considera que o evento do qual Lima Barreto pode ser testis é justamente o supracitado “projeto político e psiquiátrico de exclusão dos 'doentes mentais' do espaço público na Primeira República". ${ }^{37}$ Acreditamos que tal dimensão pode ser observada principalmente nas diversas descrições dos procedimentos, rotinas e espaços do hospício que permeiam o texto, embora não esteja ausente de diversos outros trechos mais pessoais (na realidade, tal separação se dará sempre por predominância e não por exclusividade). Um bom exemplo que possibilita essa interpretação é a descrição dos procedimentos aos quais o interno indigente se submete quando adentra o hospício: a troca de roupa, a caneca de mate, o colchão de capim, todos presentes no trecho citado mais acima.

Podemos entrever essa característica de um terceiro que testemunha, ainda, na alusão a alguns momentos em que algum fato rompe com a rotina, os espaços e os procedimentos habituais:

[27/01/1920]

Revolta dos presos na casa-forte, às sete horas da noite. Baderna, etc. A revolta é capitaneada pelo D. E., o tal que subiu no telhado. Estão chegando bombeiros e força de polícia.

\footnotetext{
${ }^{36}$ BARRETO. Um longo sonho de futuro: diários, cartas, entrevistas e confissões dispersas, p. 165-166.

${ }^{37}$ BIRMAN. Escrita e experiência do cárcere em Lima Barreto e Graciliano Ramos, p. 80.
} 
Previ isto. Os revoltosos são vizinhos de quase metade da Seção Pinel. Armaram-se de trancas. Vejo-os cá de cima. O resto da Seção Pinel mantém calma. A nossa está quase sem guardas nem enfermeiros, mas a atitude de todos é de curiosidade. Um acontecimento desses quebra a monotonia e distrai. ${ }^{38}$

Em trechos como esse, o escritor parece se apresentar extremamente distante, frio e indiferente em relação aos eventos do hospício. Tal distanciamento, muitas vezes presente, traz à tona outra questão sobre essa pessoa que testemunha. Diferentemente do que postula a teoria do testimonio, não podemos, aqui, pensar facilmente em um ser coletivo, indivíduo exemplar de um grupo de oprimidos. Em diversos trechos há um esforço deliberado por parte de Lima Barreto de se distanciar dos outros internos, marcando sua cultura e sua lucidez.

\section{[26/01/1920]}

Na primeira vez que aqui estive, consegui não me intrometer muito na vida do hospício; agora não, sou a isso obrigado, pois todos me procuram e contam-me mexericos e novidades.

Esse convívio, obrigado, com indivíduos dos quais não gostamos, é para mim, hoje, insuportável e ainda mais esse furto e as minhas apavorantes dívidas fazem-me desejar imensamente sair daqui. ${ }^{39}$

Há de se evocar, também, novamente, a distinção que Valeria de Marco faz acerca das duas acepções de testemunho na América Latina. Não acreditamos que haja possibilidade de pensar o Diário do hospício de Lima Barreto no viés democratizante da inclusão do discurso do subalterno na cultura letrada. A segunda acepção de testemunho evocada por ela pode interpretar melhor a figura desta testemunha: o texto de Lima Barreto, escritor e intelectual, aparece como uma crítica essencialmente letrada de alguém que se opõe a um certo regime ou discurso, e não como um movimento que dá voz aos excluídos, possibilitando que seu discurso chegue ao centro. Há de se fazer referência às concepções de infâmia e falsa infâmia (ou fama às avessas), retiradas de Foucault, que Maria Isabel Edom Pires usa para pensar a situação de Lima Barreto.

Existe uma falsa infâmia, aquela que desfrutam homens de pavor ou de escândalo como o foram Gilles de Rais, Guilleri ou Cartouche, Sade e Lacenaire. Aparentemente infames, por causa das abomináveis recordações que deixaram, das malfeitorias que se lhes atribuem, do respeitoso horror que inspiraram, são de fato homens de lenda gloriosa, mesmo que as razões desse renome sejam inversas das que fazem, ou deveriam fazer, a grandeza humana. A infâmia deles não é mais do que uma modalidade da universal fama. Mas o monge apóstata, mas os pobres espíritos extraviados por caminhos

\footnotetext{
${ }^{38}$ BARRETO. Um longo sonho de futuro: diários, cartas, entrevistas e confissões dispersas, p. 203.

${ }^{39}$ BARRETO. Um longo sonho de futuro: diários, cartas, entrevistas e confissões dispersas, p. 201.
} 
desconhecidos, esses são infames a todo o rigor; já não existem senão por via das poucas palavras terríveis que estavam destinadas a torná-los indignos, para sempre, na memória dos homens. ${ }^{40}$

Tal autora considera que "vida e obra de Lima Barreto circulam ambiguamente pela noção de 'infâmia' e 'fama às avessas"”. 41 Acreditamos, no entanto, que sua situação está muito mais próxima, ao menos atualmente, da "fama às avessas" do que da infâmia. Há de se convir, ainda, que escritos como esse Diário do hospício dificilmente ganhariam tanta publicidade e chegariam a tão grande público se não tivessem sido escritos por um escritor já bem conhecido, embora não consagrado em vida, se tivessem sido escritos pelo muitos prováveis infames do HNA.

Essas tentativas de distanciamento muitas vezes fazem com que a ênfase de sua escrita se dê na sua visão individual e subjetiva de alguém que passa por uma situação-limite e sobrevive para contá-la. Na sua visão de superstis, portanto. Tem-se afirmado, em muitas ocasiões, a questão da intraduzibilidade especial das experiências-limite e de vivências violentas e da impossibilidade de ler as tentativas de descrição dessas vivências como descrições realistas, especialmente nos setores que estudam o testemunho entendido como Zeugnis. Acreditamos que algo parecido com essa indizibilidade da experiência aparece também nesses diários de Lima Barreto. É possível formular a hipótese de que, em determinados momentos, a incapacidade de exprimir total ou propriamente sua situação como interno do hospício faz com que ele desloque sua experiência em direção a conhecidas experiências de outros escritores ou de personagens de ficção. Talvez possamos ver, aí, ligeira semelhança com o uso que Primo Levi faz do Inferno de Dante.

[04/01/1920]

Da outra vez, fui para a casa-forte e ele me fez baldear a varanda, lavar o banheiro, onde me deu um excelente banho de ducha de chicote. Todos nós estávamos nus, as portas abertas, e eu tive muito pudor. Eu me lembrei do banho de vapor de Dostoievski, na Casa dos Mortos.

Quando baldeei, chorei; mas lembrei de Cervantes, do próprio Dostoievski, que pior deviam ter sofrido em Argel e na Sibéria.

Ah! A Literatura ou me mata ou me dá o que eu peço dela. ${ }^{42}$

\footnotetext{
${ }^{40}$ FOUCAULT citado por PIRES. Lima Barreto - diário de um intelectual encarcerado, p. 71.

${ }^{41}$ PIRES. Lima Barreto - diário de um intelectual encarcerado, p. 71.

${ }^{42}$ BARRETO. Um longo sonho de futuro: diários, cartas, entrevistas e confissões dispersas, p. 154.
} 
Estou entre mais de uma centena de homens, entre os quais passo como um ser estranho. Não será bem isso, pois vejo bem que são meus semelhantes. Eu passo e perpasso por eles como um ser vivente entre sombras - mas que sombras, que espíritos?! As que cercavam Dante tinham em comum o stock de idéias indispensável para compreendê-lo; estas não têm mais um para me compreender, parecendo que têm um outro diferente, se tiverem algum. ${ }^{43}$

No entanto, a persistência da questão da diferenciação entre e o escritor e os outros internos, somada ao fato de tais deslocamentos se darem em direção a escritores canônicos, faz com que tais movimentos possam ser vistos, pelo menos, em uma dupla interpretação, que incluiria também a tentativa de construção de uma imagem de si - ou de uma memória de si para a posteridade que marca o escritor Lima Barreto - em detrimento de outros "títulos" que pudesse receber - através da projeção de sua imagem e de sua vida sobre a imagem e a vida destes outros escritores. Vale ressaltar que tal movimento de construção de imagem e de aproximação a outros escritores parece ser algo bastante comum em diários de escritor, como sugere Ávila. ${ }^{44}$

\section{O TESTEMUNHO}

Tentamos frisar no início de nosso texto a fragmentação e a impossibilidade estrutural de totalização colocada pela forma do diário. Nesse sentido, poderíamos aproximar sua forma à do testemunho entendido como Zeugnis, embora tal semelhança formal se dê através de caminhos bem diversos. No entanto, acreditamos que, em muitos momentos, há um certo tom de reportagem que poderia aproximar o texto de que tratamos do testimonio. Pensamos ter deixado aparecer esse tom de reportagem em alguns dos trechos citados, especialmente no que diz respeito à descrição de procedimentos, rotinas, etc.

Há um ponto, no entanto, que afasta brutalmente o Diário do hospício de ambas as acepções do testemunho: a questão do real e da ficção. Poderíamos dizer que tanto o testemunho entendido como Zeugnis quanto o testemunho entendido como testimonio se sustentam sobre o imperativo ético do caráter não fictício de seus textos. Poderíamos dizer que, nesses gêneros, há uma espécie de interdição em considerar o pacto que ali se firma como mero pacto.

\footnotetext{
${ }^{43}$ BARRETO. Um longo sonho de futuro: diários, cartas, entrevistas e confissões dispersas, p. 160.

${ }^{44}$ ÁVILA. O diário e a diáspora, p. 235.
} 
O Diário do hospício de Lima Barreto estabelece, desde o princípio, o pacto autobiográfico, que, aliás, é característico de qualquer diário. Mas não podemos nos esquecer de que as notas foram pensadas também como matéria-prima para escrita de um romance, e de que, afinal, todos os diários de escritor - ao menos os que já tivemos a oportunidade de consultar conjugam a escrita da vivência com o trabalho ficcional. Desse modo, no meio de suas notas, emergem, muitas vezes, traços explicitamente ficcionais. Há um momento paradigmático desse movimento nesses diários, por ser o primeiro e por se apresentar de modo abrupto. Neste trecho, sem que haja nenhum aviso, separação ou mudança de tom, o pacto autobiográfico é rompido, e o personagem emerge como um outro eu que não o próprio autor:

Mas na Seção Pinel, aconteceu-me coisa mais manifesta, da estupidez do guarda
e da sua crença de que era meu feitor e senhor. Era este um rapazola de vinte e
tantos anos, brasileiro, de cabeleira solta, com um ar de violeiro e modinheiro.
Estava deitado no dormitório que me tinham marcado e ele chegou à porta e
perguntou:
- Quem é aí Tito Flamínio?
- Sou eu, apressei-me.
- O seu S. A. manda dizer que você e sua cama vão para o quarto do doutor Q.

A emergência da ficção nesse momento de suas notas, do modo como acontece, de certo modo contamina todo o restante do texto de uma certa indecidibilidade quanto ao caráter de registro ou de ficcionalização de seu texto. Podemos dizer que esse texto aceita a ficcionalização. Não há um imperativo ético que a interdite. Acreditamos, na realidade, que tal movimento já está parcialmente presente nas aproximações que faz entre sua situação, e os textos de Dostoiévski e Dante, que já não levam em conta um limite estrito entre ficcional e biográfico.

Não acreditamos, no entanto, que seja o caso de descartar, por esse motivo, o valor histórico e memorialístico de suas notas. Procuramos demonstrar, ao longo do texto, que tais notas podem, sim, fornecer pontos de vista pertinentes para o pensamento acerca da memória pessoal, da história e das suas inter-relações. Se em certo momento o pacto autobiográfico é quebrado, isso não autoriza a classificação de todo o seu discurso como mentira. Esses textos produzidos durante sua estadia no hospício, independentemente de suas relações com a ficção, permanecem habitados por uma espécie de indício do real, embora não entendido de forma totalizante ou objetiva, além de possuírem trechos, questões e reflexões que ainda hoje são

\footnotetext{
${ }^{45}$ BARRETO. Um longo sonho de futuro: diários, cartas, entrevistas e confissões dispersas, p. 173.
} 
pertinentes para pensarmos a loucura, a ciência, a modernidade e a contemporaneidade, além da própria questão da referência e da representação na literatura.

\begin{abstract}
This paper intends to use the theory of testimony as a starting point for the analysis of Lima Barreto's Diário do hospício, although respecting the particularities of the diary. The text seems to accept multiple interpretations, presenting itself as both a testimony of a system of exclusion and a work of construction of the writer's self-image.
\end{abstract}

\title{
KEYWORDS
}

Writer's diary, testimony, writer's image

\section{REFERENCIAS}

ÁVILA, Myriam. Invenção e inventário no diário de escritor. Inédito, 2007.

ÁVILA, Myriam. O diário e a diáspora. IPOTESI, Juiz de Fora, v. 15, n. 1, p. 234-240, jan./jun. 2011.

BARRETO, Lima. Um longo sonho do futuro: diários, cartas, entrevistas e confissões dispersas. Rio de Janeiro: Graphia, 1998.

BENJAMIN, Walter. Obras escolhidas volume 1: Magia e técnica, arte e política. Trad. Sergio Paulo Rouanet. São Paulo: Brasiliense, 1994.

BIRMAN, Daniela. Escrita e experiência do cárcere em Lima Barreto e Graciliano Ramos. Literatura e autoritarismo, Santa Maria, Dossiê escritas da violência II, jul. 2010. Disponível em: $<$ http://w3.ufsm.br/grpesqla/revista/dossie03/art_08.php>. Acesso em: 27 fev. 2012.

COSTA, Raul M. L. da. Alcoolismo, discurso científico e escrita de si no Diário do hospício de Lima Barreto. Antíteses, Londrina, v. 1, n. 1, p. 188-208, jan./jun. 2008.

FIGUEIREDO, Carmen L. N. O arquivo e o olhar: da vida literária à rede de imagens culturais. Matraga, Rio de Janeiro, v. 14, n. 21, jul./dez. 2007.

LIS, Jerzy. Le journal d'écrivain en France dans la 1ère moitié du XXe siècle: à la recherche d'un code générique. Poznan: A. Mickiewicz, 1996. (Uniwersytet IM. Adama Mictiewicza. (Seria Filologia Romańska; n. 20)

MARCO, Valeria de. A literatura de testemunho e a violência de Estado. Lua Nova, São Paulo, n. 62, p. 45-68, 2004. 
MATHIAS, Marcello D. Autobiografias e diários. Colóquio Letras, Lisboa, n. 143-144, p. 41-62, jan./jun. 1997.

PIRES, Maria I. E. Lima Barreto - diário de um intelectual encarcerado. Vivência, Natal, n. 30, p. 15-23, 2006.

SELIGMANN-SILVA, Márcio. "Zeugnis" e "Testimonio": um caso de intraduzibilidade entre conceitos. Letras - "Literatura e Autoritarismo", Santa Maria, n. 22, p. 121-130, jan./jun. 2001.

SELIGMANN-SILVA, Márcio. Reflexões sobre a memória, a história e o esquecimento. In: . (Org.). História, memória, literatura: o testemunho na Era das Catástrofes. Campinas: Editora Unicamp, 2003. p. 59-89. 